Mexican Journal of Biotechnology 2019, 4(4):50-64

Journal homepage:www.mexjbiotechnol.com

ISSN:2448-6590

SHORT COMMUNICATION

\title{
Production of cutinolytic esterase by Fusarium culmorum grown at different apple cutin concentrations in submerged fermentation
}

\section{Producción de esterasa cutinolítica por Fusarium culmorum crecido en diferentes concentraciones de cutina de manzana en fermentación sumergida}

Angel González-Márquez², Octavio Loera-Corral ${ }^{3}$, Gustavo Viniegra-González ${ }^{3}$, Carmen Sánchez ${ }^{1 *}$

${ }^{1}$ Laboratory of Biotechnology, Research Centre for Biological Sciences, Universidad Autónoma de Tlaxcala, Ixtacuixtla, CP. 90062, Tlaxcala, Mexico.

${ }^{2}$ Doctorado en Biotecnología, Universidad Autónoma Metropolitana-Iztapalapa, Av. San Rafael Atlixco N 186, Col. Vicentina C.P. 09340, Iztapalapa, CDMX, Mexico. ${ }^{3}$ Departamento de Biotecnología, Universidad Autónoma Metropolitana-Iztapalapa, Av. San Rafael Atlixco N 186, Col. Vicentina C.P. 09340, Iztapalapa, CDMX, Mexico.

${ }^{*}$ Corresponding author

E-mail address: carmen.sanchezh@uatx.mx (C. Sánchez).

Article history:

Received: 4 October 2019 / Received in revised form: 10 November 2019 / Accepted: 18 November 2019 / Published online: 19 November 2019.

https://doi.org/10.29267/mxib.2019.4.4.50

\begin{abstract}
Cutinolytic esterase (i.e., cutinase) is an enzyme that catalyzes the cleavage of ester bonds in cutin and also in diverse soluble and insoluble esters. It has application in several biotechnological areas, acting as biocatalysts in the food industry, in detergents, in biodegradation of polymers and other toxic substances, being important in biorremediation. In this research, specific growth rate, protein content, cutinolytic activity by biochemical tests and polyacrylamide gel electrophoresis, and growth and enzymatic kinetic parameters were determined for $F$. culmorum grown at different apple cutin concentrations $(0.2,2$ and $20 \mathrm{~g} / \mathrm{L})$ in submerged fermentation. It was observed that biomass, protein content and enzymatic activity enhanced as
\end{abstract}


cutin concentration increased in the media. A cutinase activity band of around 65 $\mathrm{KDa}$ was observed in zymograms of different cutin concentration. An additional cutinase activity band of around $90 \mathrm{KDa}$ was also observed in zymograms of $F$. culmorum grown in $20 \mathrm{~g}$ of apple cutin/L. These studies showed that $F$. culmorum used apple cutin as the sole carbon source, which acted as a cutinase inducer. The highest-yielding parameters of cutinase were observed in $2 \mathrm{~g}$ of apple cutin/L. This research showed promising results in the cutinase induction for $F$. culmorum using a low concentration of apple cutin.

Keywords: Apple cutin, cutinases, Fusarium culmorum, submerged fermentation.

\section{RESUMEN}

La esterasa cutinolítica (i.e. cutinasa) es una enzima que cataliza la ruptura de los enlaces éster en la cutina y también en una variedad de ésteres sintéticos solubles e insolubles. Esta enzima tiene aplicación en varias áreas biotecnológicas, actuando como biocatalizadores en la industria alimentaria, en detergentes, en biodegradación de polímeros y otras sustancias tóxicas, siendo importante en la biorremediación. La tasa de crecimiento específica, el contenido de proteínas, la actividad de esterase cutinolítica mediante pruebas bioquímicas y de electroforesis en gel de poliacrilamida, y los parámetros cinéticos de crecimiento y enzimáticos se determinaron para $F$. culmorum cultivado en diferentes concentraciones de cutina de manzana $(0.2,2$ y $20 \mathrm{~g} / \mathrm{L})$ en fermentación sumergida. Se observó que la biomasa, el contenido de proteínas y la actividad enzimática aumentaron conforme aumentó la concentración de cutina en los medios. Se observó una banda de actividad de cutinasa de aproximadamente $65 \mathrm{KDa}$ en los zimogramas de las diferentes concentraciones de cutina probadas. Una banda adicional de actividad de cutinasa de aproximadamente $90 \mathrm{KDa}$ fue observada en zimogramas de $F$. culmorum crecido en $20 \mathrm{~g}$ de cutina de manzana /L. Estos estudios mostraron que F. culmorum empleó la cutina de manzana como la única fuente de carbono, misma que actuó como un inductor de cutinasa. Los parámetros de rendimiento más altos de ésta enzima fueron observados en $2 \mathrm{~g}$ de cutina de manzana/L. Esta investigación mostró resultados prometedores en la inducción de cutinasa en $F$. culmorum usando bajas concentraciones de cutina de manzana.

Palabras clave: Cutinasas, cutina de manzana, fermentación sumergida. Fusarium culmorum.

\section{INTRODUCTION}

Cutinolytic esterase (i.e., cutinase) is known as cutin hydrolase (EC 3.1.1.74) and it is an enzyme that catalyzes not only the cleavage of ester bonds in cutin but also in diverse soluble and insoluble esters, insoluble triglycerides, phthalates, plastics and 
others (Kim et al., 2003; Chen et al., 2013; Nyyssölä, 2015; Ferrario et al., 2016; Ferrer-Parra et al., 2018). Cutinase is an extracellular enzyme produced by several phytopathogenic fungi that grow in cutin as sole carbon source. Cutin is a high molecular weight and insoluble biopolymer composed of epoxy and interesterified hydroxy fatty acids that forms the structural component of higher plants cuticle, and that function as a structural support (Pio \& Macedo, 2009; Fich et al., 2016). Cutinase shares properties of lipase and esterase in its catalytic action, since it is a serine esterase with the classical Ser-His-Asp triad similar to several lipases and serine proteases (Nyyssölä, 2015). This enzyme presents a unique feature of being active regardless the presence of an oil-water interface, making it attractive as a biocatalyst for several promising industrial applications like inter- and intra-transesterification reactions (Pio \& Macedo, 2009). These properties of cutinase are being used for several applications in agriculture, in the textile industry, in household detergents, in pharmaceuticals, in processing food and dairy, in biocatalysis, in detoxification of environmental pollutants etc. (Nyyssölä, 2015). Therefore, cutinase is an important industrial catalyst that replaces older technologies with environmentally friendly processes (Chen et al., 2013). It is known the importance of the carbon source for the growth of the microorganisms and its influence on the enzyme parameters such as productivity, yield, and specific rate of enzyme production. It has been reported that cutin from the natural and agro industrial wastes offer advantages over pure or synthetic analogues of cutin with respect to cutinase production (Fett et al., 1999; Pio \& Macedo, 2009). Plant cutin acts as an important inducer of cutinase enzyme for different fungal species. Several studies have reported that Fusarium species are able to produce cutinase (Kim et al., 2007; Fraga et al., 2012; Canavati-Alatorre et al., 2017; De Oliveira et al., 2019). In this research, different concentrations of apple peels cutin were evaluated for growth and cutinase production by Fusarium culmorum in submerged fermentation. Fungal specific growth rate, enzymatic activity (biochemical and zymogram analysis), protein content, growth and enzymatic kinetic parameters were determined.

\section{MATERIALS AND METHODS}

\subsection{Strain}

F. culmorum from the culture collection of the Research Centre for Biological Sciences (CICB) at Universidad Autónoma de Tlaxcala, Mexico was used. This strain was isolated from a recycled paper industry (Aguilar-Alvarado et al., 2015). The strain was grown on malt extract agar (Difco) at $20^{\circ} \mathrm{C}$ and stored at $4{ }^{\circ} \mathrm{C}$.

\subsection{Culture media and culture conditions}


Three liquid culture media were prepared: 1 ) Mineral medium (MM) $+0.2 \mathrm{~g}$ of apple peels cutin/L 2) $M M+2 \mathrm{~g}$ of apple peels cutin/L, 3) $M M+20 \mathrm{~g}$ of apple peels cutin/L. MM contained (in $\mathrm{g} / \mathrm{L}$ ), $0.6 \mathrm{KH}_{2} \mathrm{PO}_{4}, 0.001 \mathrm{ZnSO}_{4} \cdot 7 \mathrm{H}_{2} \mathrm{O}, 0.4 \mathrm{~K}_{2} \mathrm{HPO}_{4}, 0.05$ $\mathrm{FeSO}_{4} \cdot 7 \mathrm{H}_{2} \mathrm{O}, 0.05 \mathrm{MnSO}_{4} \cdot \mathrm{H}_{2} \mathrm{O}, 0.5 \mathrm{MgSO}_{4} \cdot 7 \mathrm{H}_{2} \mathrm{O}, 0.25 \mathrm{CuSO}_{4}$. Each medium was supplemented with $5 \mathrm{~g}$ of yeast extract as nitrogen source. The $\mathrm{pH}$ was adjusted to 6.5 using $0.1 \mathrm{M} \mathrm{HCl}$ or $0.1 \mathrm{M} \mathrm{NaOH}$ as required. Flasks of $125 \mathrm{~mL}$ containing $50 \mathrm{~mL}$ of culture medium were autoclaved at $120^{\circ} \mathrm{C}$ for $15 \mathrm{~min}$, cooled to room temperature and then inoculated with three mycelial plugs (of $10 \mathrm{~mm}$ diameter) taken from the periphery of 7-day-old colonies of $F$. culmorum grown on malt extract agar (DIFCO). Cultures were incubated at $25^{\circ} \mathrm{C}$ for 7 days (168 h) on a rotary shaker at $130 \mathrm{rpm}$. Analyses were carried out on samples taken at 12-h intervals and performed in triplicate.

\subsection{Cutin extraction}

Cutin was extracted from the cuticle of apples (Golden Delicious, purchased on the local market), using the method described by Macedo \& Pio (2005). Apples were peeled and peels were placed in a beaker, and then a buffer solution of sodium oxalate at $\mathrm{pH}$ of 3.5 was added. Peels were boiled for $30 \mathrm{~min}$ in order to separate the pulp remaining from the peels. Peels were filtered and freeze-dried at $-40{ }^{\circ} \mathrm{C}$ (for $12 \mathrm{~h})$ and then lyophilized. A solution of methanol and dichloromethane $(1: 1 \mathrm{v} / \mathrm{v})$ was added to the lyophilized material and then left overnight. Cutin powder was obtained from that solution by rotary evaporation at $45^{\circ} \mathrm{C}$.

\subsection{Growth and estimation of kinetic parameters}

Biomass $(X)$ was obtained by filtration of the samples and the specific growth rate was determined from changes in dry weight, using the logistic equation as reported previously (Ahuactzin-Pérez et al., 2016). The specific growth rate $(\mu)$ was estimated as reported by Ahuactzin-Pérez et al. (2016). $X_{\max }$ corresponds to the maximal biomass produced by the fungus during the exponential growth.

\subsection{Protein content and $\mathrm{pH}$ measurements}

Culture supernatants were used to determine the protein production using Bradford (1976) protein assay. $960 \mathrm{~mL}$ of Bradford reagent (Bio-Rad) added to a test tube with $40 \mathrm{~mL}$ of each supernatant. Protein production was evaluated by using a UNICO spectrophotometer (S-2150 series, DAYTON, NJ, USA) at $595 \mathrm{~nm}$. The $\mathrm{pH}$ was measured every $12 \mathrm{~h}$ in the supernatant of the cultures using a digital potentiometer (Hanna Instruments, México).

\subsection{Cutinase activity and estimation of enzymatic parameters}

Cutinase activity was evaluated by spectrophotometry at $405 \mathrm{~nm}$ by adding $900 \mu \mathrm{L}$ of substrate and $100 \mu \mathrm{L}$ of supernatant sample. The reaction mixture contained $1.76 \%$ of $p$-nitrophenyl butyrate ( $p$ NPB), $1.1 \%$ of acetonitrile, $11.1 \%$ of distilled water, $0.04 \%$ of Triton X-100 and was diluted with $0.01 \mathrm{M}$ phosphate buffer $(\mathrm{pH} 7.5)$ 
(Canavati-Alatorre et al., 2016). One unit of cutinolytic activity was defined as the amount of cutinase required to release one micromole of $p$-nitrophenol in one minute (Macedo \& Pio, 2005). Yield of enzyme per unit of biomass produced by the fungus $\left(Y_{E / X}\right)$ was estimated as the relation between maximal enzymatic activity obtained during the exponential growth $\left(E_{\max }\right)$ and $X_{\max }$. Enzymatic productivity was evaluated at that time when the enzymatic activity was maximal ( $P=E_{\max } /$ time). The specific rate of enzyme production was calculated from the equation: $q_{p}=(\mu)\left(Y_{E / X}\right)$ (Ahuactzin-Pérez et al., 2016).

\subsection{Zymography}

The samples with cutinase activity were analyzed by electrophoresis in $0.1 \%$ polyacrylamide gels with sodium dodecyl sulfate (SDS-PAGE) (Laemmli, 1970). $12 \%$ and $4 \%$ acrylamide gels were used as separation and packaging gels, respectively. Precision Plus Protein ${ }^{\mathrm{TM}}$ Dual Xtra Standards (Bio-Rad) was used as molecular weight marker. Samples were tested on gels of $0.75 \mathrm{~mm}$ in a Mini Protean electrophoresis system Tetra Cell (Bio-Rad) at 100 volts for $1.30 \mathrm{~h}$ and the procedure was carried out as previously reported (Karpushova et al., 2005; Canavati-Alatorre et al., 2016). Cutinase activity was observed as red-colored bands in the gels.

\section{RESULTS}

\subsection{Biomass production and specific growth rate}

Growth curves of $F$. culmorum on media added with different concentrations of apple cutin are shown in Fig. 1. The highest biomass production was obtained in medium containing $20 \mathrm{~g}$ of cutin/L followed by those media added with 2 and $0.2 \mathrm{~g}$ of cutin/L (Fig.1; Table 1). However, there were no significant differences in the $\mu$ values showed in the different media tested (Table 1).

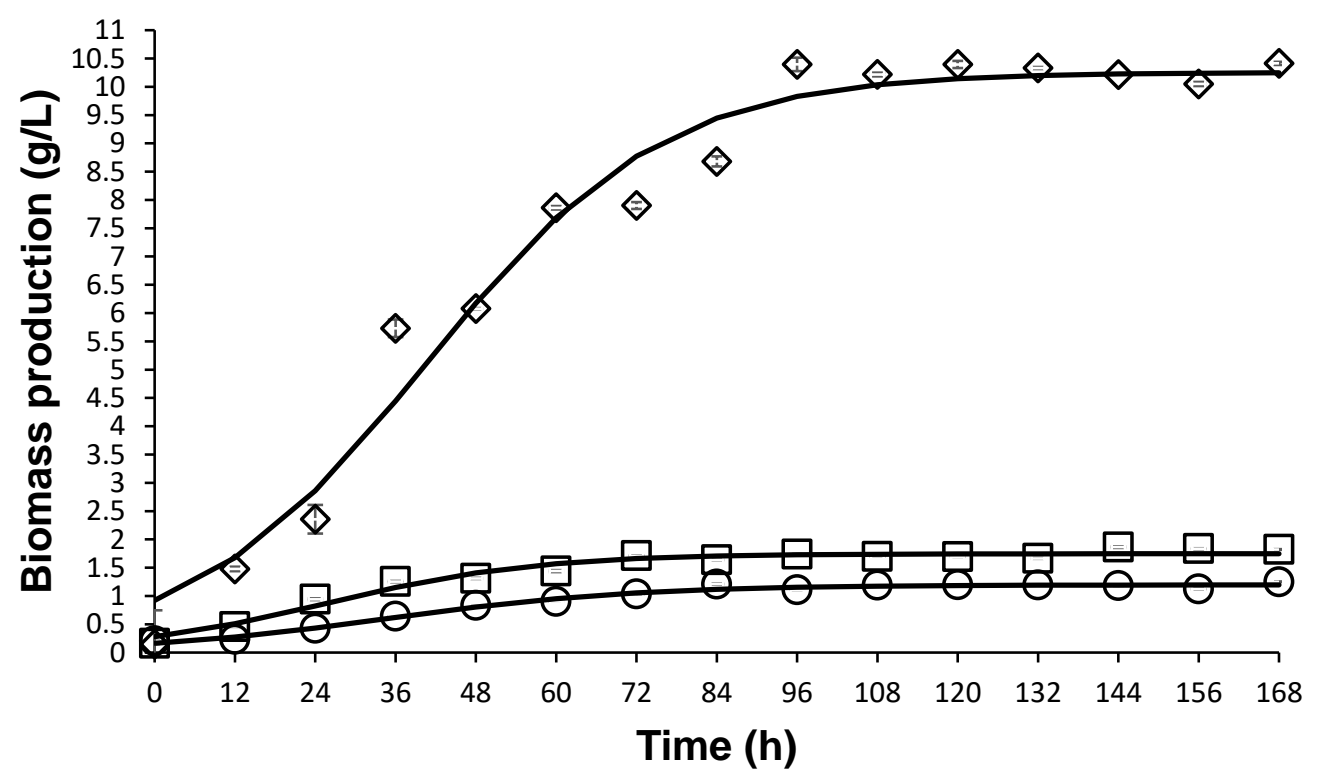


Fig.1. Biomass production by $F$. culmorum grown on media supplemented with 0.2 (o), $2(\square)$ and $20(\diamond) \mathrm{g}$ of apple cutin/L in submerged fermentation.

Table 1. Growth parameters and yield parameters of cutinase of $F$. culmorum grown in media supplemented with different concentrations of apple cutin under submerged fermentation.

\begin{tabular}{|c|c|c|c|}
\hline \multirow[t]{2}{*}{ Parameters } & \multicolumn{3}{|c|}{$\begin{array}{l}\text { Culture media supplemented with apple cutin } \\
\qquad(\mathrm{g} / \mathrm{L})\end{array}$} \\
\hline & 0.2 & $2 \mathrm{~g}$ & $20 \mathrm{~g}$ \\
\hline \multicolumn{4}{|c|}{ Growth parameters } \\
\hline$\mu\left(h^{-1}\right)$ & $0.05 \pm 0.001^{a}$ & $0.06 \pm 0.001^{a}$ & $0.05 \pm 0.001^{a}$ \\
\hline$X_{\max }(g / L)$ & $1.19 \pm 0.01^{c}$ & $1.74 \pm 0.01^{b}$ & $10.25 \pm 0.01^{a}$ \\
\hline \multicolumn{4}{|c|}{ Yield parameters of cutinase } \\
\hline $\mathrm{E}_{\max }(\mathrm{U} / \mathrm{L})$ & $251.6 \pm 0.1^{c}$ & $360.9 \pm 0.3^{b}$ & $434.1 \pm 0.2^{a}$ \\
\hline$Y_{E / X}(U / g / X)$ & $211.4 \pm 5^{a}$ & $207.4 \pm 6^{a}$ & $42.4 \pm 3^{b}$ \\
\hline$P_{\mathrm{RO}}\left(\mathrm{U} / \mathrm{L}^{*} \mathrm{~h}\right)$ & $1.49 \pm 0.01^{b}$ & $3.00 \pm 0.01^{a}$ & $3.01 \pm 0.01^{a}$ \\
\hline$q_{p}\left(\left(U / g X^{*} h\right)\right)$ & $10.57 \pm 0.01^{b}$ & $12.44 \pm 0.02^{a}$ & $2.12 \pm 0.01^{c}$ \\
\hline
\end{tabular}

Values are expressed as mean \pm SEM $(n=3)$; means within the same column not sharing common superscript letters $(a, b, c)$ differ significantly at $5 \%$ level. Growth parameters; $X_{\max }$ and $\mu$, were evaluated using a non-linear least squares fitting program (Ahuactzin-Pérez et al., 2016). Yield parameters of esterase were calculated as previously reported (González-Márquez et al., 2019).

\subsection{Protein content analysis and $\mathrm{pH}$ measurement}

The results for protein production are shown in Fig. 2. It was observed that $F$. culmorum produced the highest protein content in the culture medium containing 20 $\mathrm{g}$ of cutin/L, showing the greatest protein content $(0.2 \mathrm{mg} / \mathrm{mL})$ after $84 \mathrm{~h}$ of fermentation. The lowest protein content was showed in those media supplemented with 2 and $0.2 \mathrm{~g}$ of cutin/L, with a maximum production of approximately $0.05 \mathrm{mg} / \mathrm{mL}$. Fig. 3 shows the $\mathrm{pH}$ of the cultures during the fermentation process. The highest values of $\mathrm{pH}$ were observed in those media supplemented with 0.2 and $2 \mathrm{~g}$ of apple cutin/L, in which the $\mathrm{pH}$ value increased to 7.7 approx. after $168 \mathrm{~h}$. The lowest $\mathrm{pH}$ values were showed in the media containing $20 \mathrm{~g}$ of apple cutin/L, reaching a maximum value of 7.2 after $168 \mathrm{~h}$. 


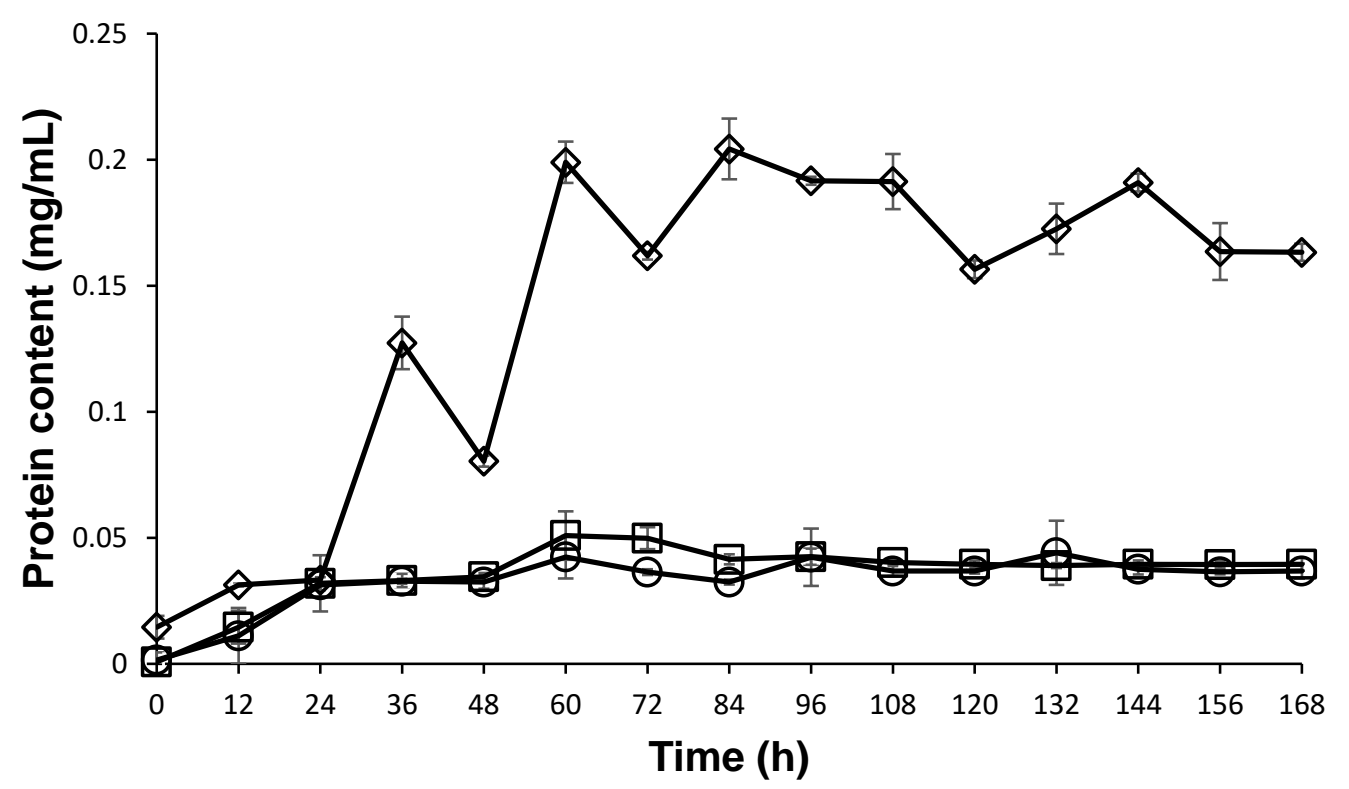

Fig. 2. Protein content of $F$. culmorum grown on media supplemented with 0.2 (o), $2(\square)$ and $20(\diamond) \mathrm{g}$ of apple cutin/L in submerged fermentation.

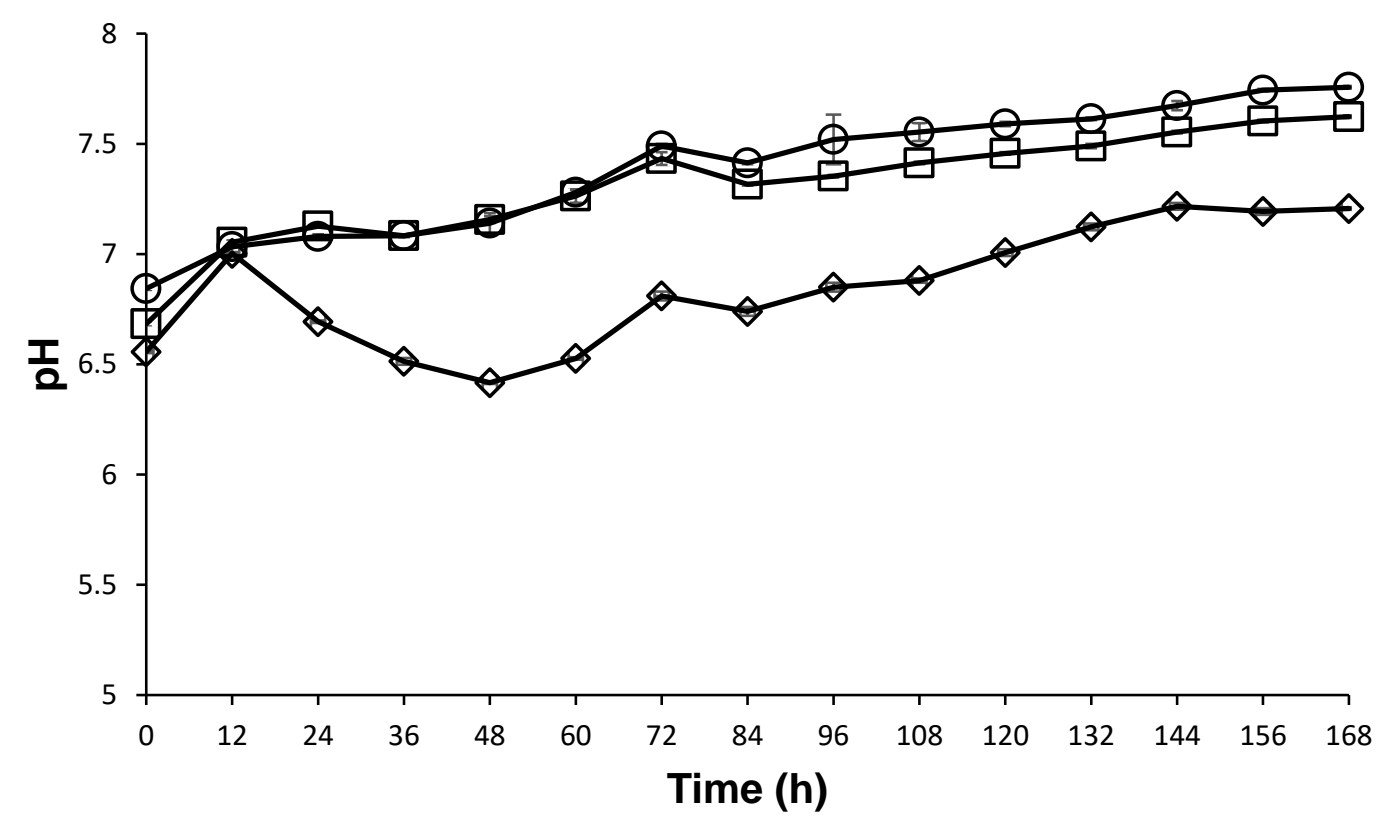

Fig. 3. $\mathrm{pH}$ of $F$. culmorum grown on media supplemented with 0.2 (o), 2 ( $\square$ ) and 20 $(\diamond) \mathrm{g}$ of apple cutin/L in submerged fermentation. 


\subsection{Cutinase specific activity}

The cutinase specific activity expressed as number of enzyme units per mg of total protein is showed in Fig. 4. The highest cutinase specific activity was showed in that medium added with $2 \mathrm{~g}$ of cutin/L, followed by the medium supplemented with $0.2 \mathrm{~g}$ of cutin/L after $84 \mathrm{~h}$. The lowest cutinase specific activity was observed in media added with $20 \mathrm{~g}$ of cutin/L. However, the greatest $E_{\max }$ was showed in the medium added with $20 \mathrm{~g}$ of cutin/L followed by those media added with 0.2 and $2 \mathrm{~g}$ of cutin/L (Table 1). Media containing 0.2 and $2 \mathrm{~g}$ of apple cutin/L had higher $\mathrm{YE}_{\mathrm{E} / \mathrm{X}}$ than that medium added with $20 \mathrm{~g}$ of cutin/L. The greatest $P_{R O}$ was shown in media supplemented with 2 and $20 \mathrm{~g}$ of apple cutin/L, followed by the medium added with $0.2 \mathrm{~g}$ of apple cutin/L. The highest-yielding parameters of cutinase $\left(Y_{E / X}, P_{\text {RO }}\right.$, and $\mathrm{q}_{\mathrm{p}}$ ) were observed in medium supplemented with $2 \mathrm{~g}$ of apple cutin/L (Table 1).

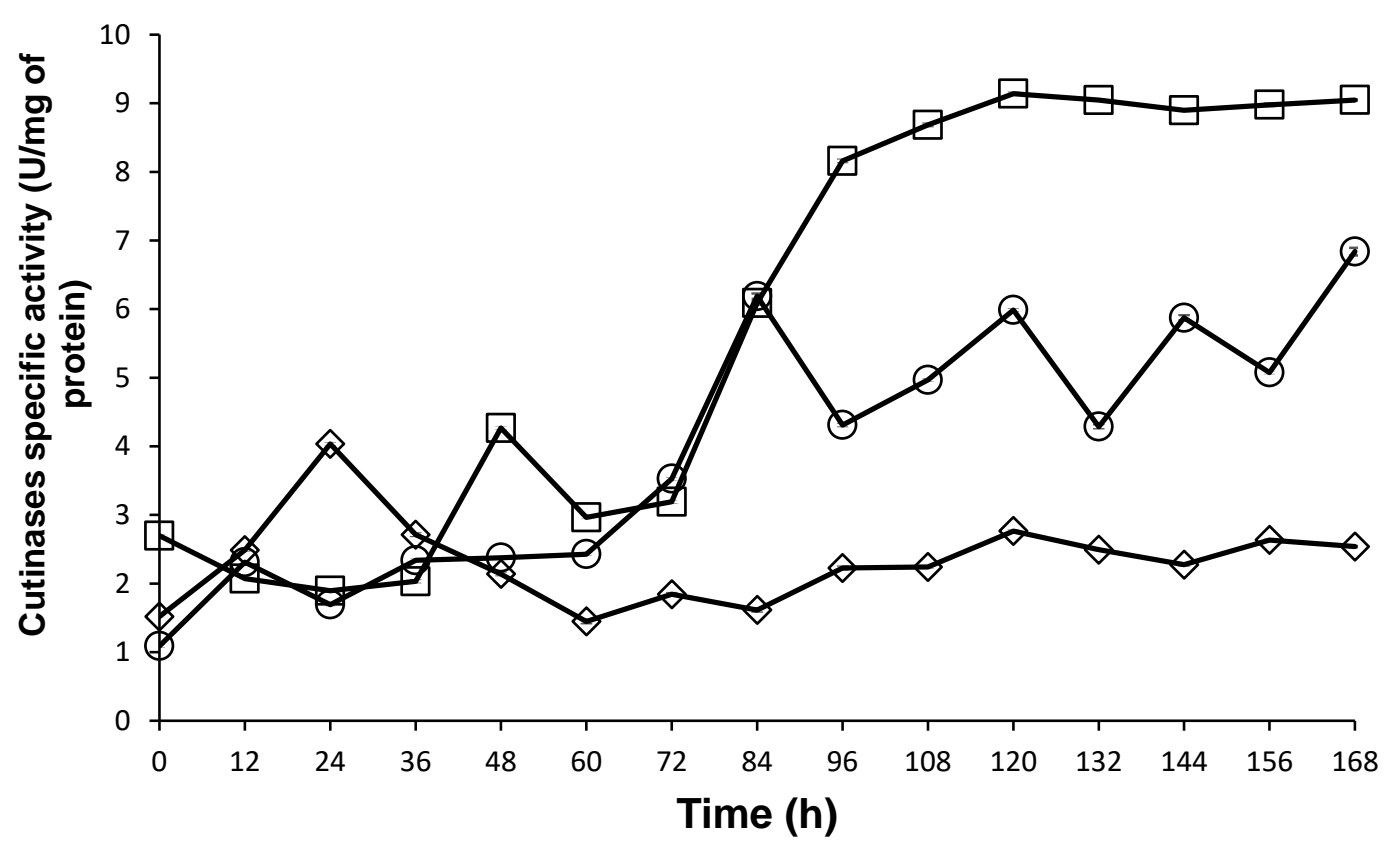

Fig. 4. Specific activity of cutinase of $F$. culmorum grown on media supplemented with $0.2(0), 2(\square)$ and $20(\diamond) \mathrm{g}$ of apple cutin/L in submerged fermentation.

\subsection{Cutinase analysis by zymography}

$E_{\max }$ data were confirmed by zymography. Cutinase zymograms of $F$. culmorum grown in 0.2 and $2 \mathrm{~g}$ of apple cutin/L are showed in Fig. 4 and Fig. 5, respectively. In these two zymograms, similar cutinase activity bands of around $65 \mathrm{KDa}$ aprox were observed after $60 \mathrm{~h}$ of fermentation (Figs. 4 and 5). Zymogram of F. culmorum grown on medium supplemented with $20 \mathrm{~g}$ of cutin/L is shown in Fig. 6. This zymogram showed higher color intensity in the bands and more cutinase activity 
bands than the rest of the zymograms. In this zymogram, a cutinase activity band of around $65 \mathrm{KDa}$, similar to that observed in zymograms of $F$. culmorum grown in low apple cutin concentration ( 0.2 and $2 \mathrm{~g}$ of apple cutin/L) was observed after $60 \mathrm{~h}$ and during all the fermentation (Fig. 6). Additionally, a cutinase activity band appeared after $36 \mathrm{~h}$ with a molecular weight of $90 \mathrm{KDa}$ approximately, which was also observed after $156 \mathrm{~h}$ (Fig. 6).

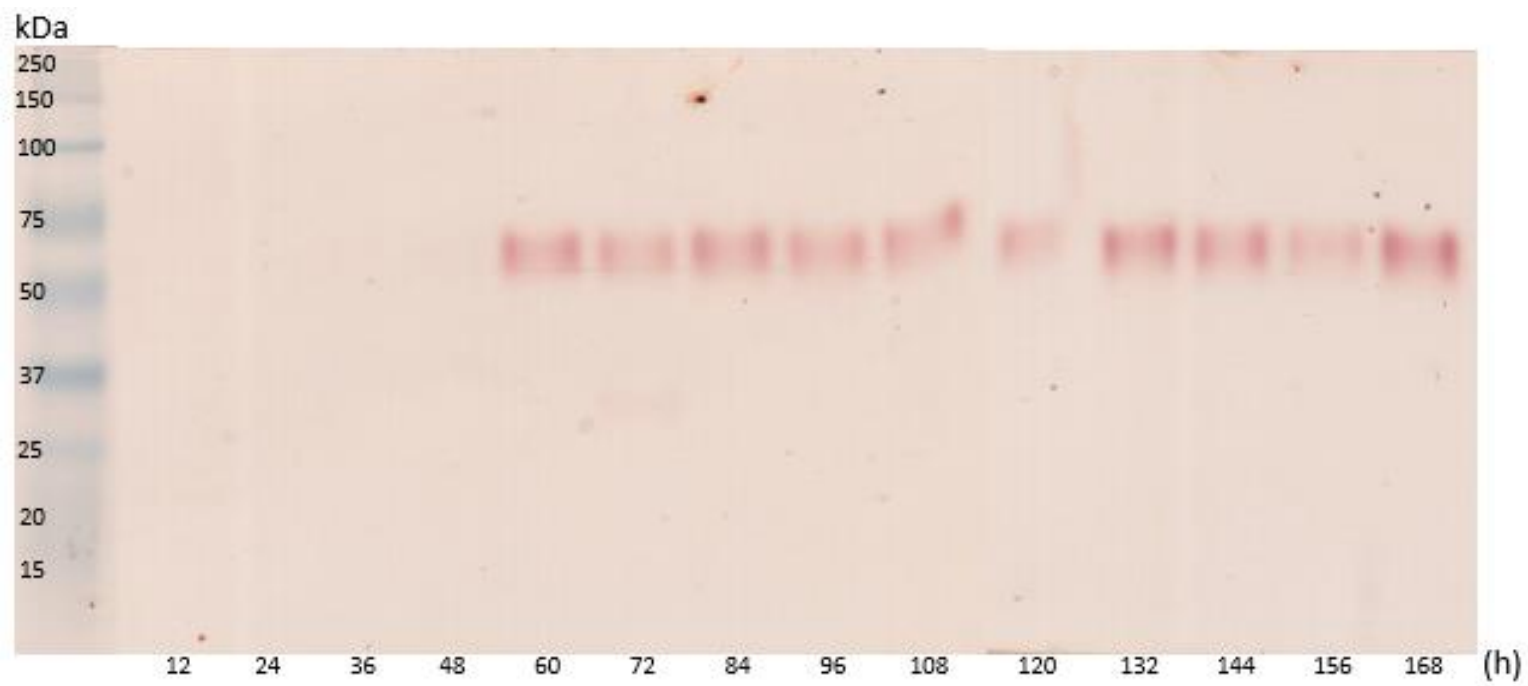

Fig. 5. Zymogram of $F$. culmorum grown on medium supplemented with $0.2 \mathrm{~g}$ of cutin/L in submerged fermentation.

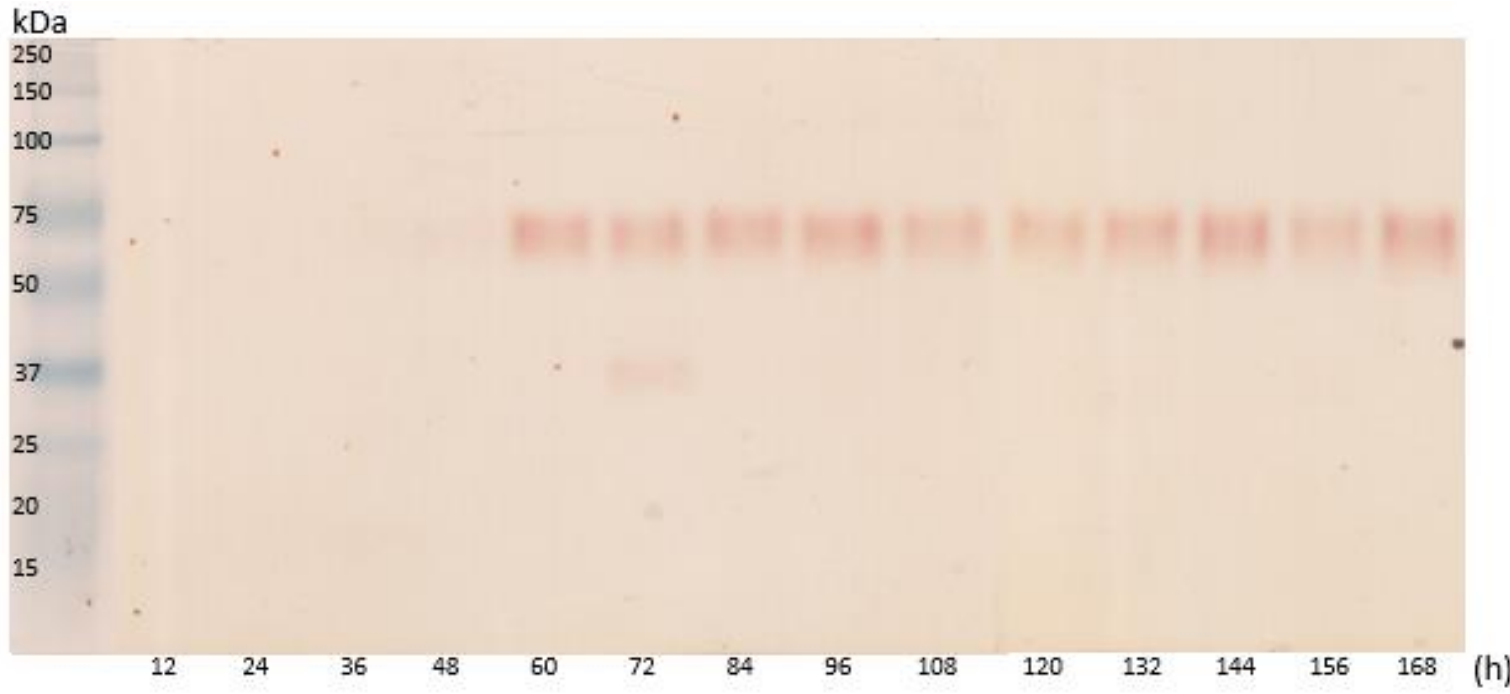

Fig. 6. Zymogram of F. culmorum grown on medium supplemented with $2 \mathrm{~g}$ of cutin/L in submerged fermentation. 


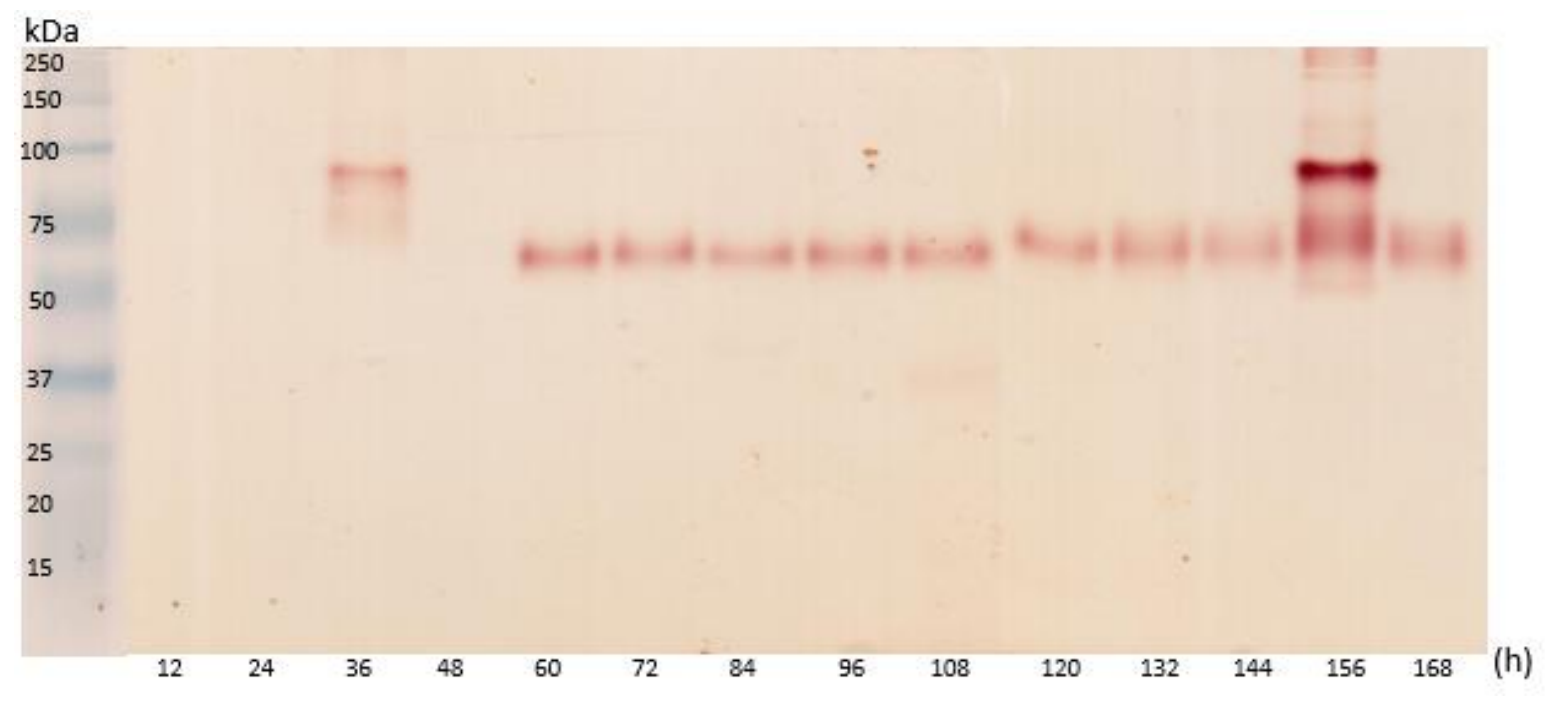

Fig. 7. Zymogram of F. culmorum grown on medium supplemented with $20 \mathrm{~g}$ of cutin/L in submerged fermentation.

\section{DISCUSSION}

Cutinase is a hydrolytic enzyme that degrade cutin, thus natural cutin has been used as a growth substrate to demonstrate cutinases identity (Chen et al., 2013). It has been reported that cutinases are produced by filamentous fungi (e.g. Fusarium species) when grown in media containing cutin or its hydrolysate (Purdy \& Kolattukudy, 1973; Lin \& Kolattukudy 1978; Degani, 2015). In the present work, apple peels cutin was used to induce cutinase in F. culmorum. It has been reported that cutin isolated from apple peels is a good cutinase inducer, since it yielded 9.64 $\mathrm{U} / \mathrm{mL}$ as compared to $6.77 \mathrm{U} / \mathrm{mL}$ of cutinase using watermelon cutin (Chaudhari \& Singhal, 2015). It was observed that $F$. culmorum grew in media supplemented with apple peels cutin as sole carbon source, using this substrate as a carbon source, since the biomass production and protein content were enhanced as cutin concentration increased in the media. The $\mathrm{pH}$ of the cultures also increased at the end of the fermentation, which could be due to the basic compounds (cutin breakdown products) releasing into the media. Degani (2015) studied production of cutinase by Fusarium oxysporum and reported that cutinase activity increases according to the amount of cutin added to the culture medium. It has been reported Induction of cutinolytic esterase activity during growth of fungal pathogens, showing that the enzymatic activity is regulated by the source and concentration of cutin (Hawthorne et al., 2001). Castro-Ochoa et al. (2012) reported cutinase production by Aspergillus nidulans using olive oil, triacylglycerides and fatty acids as inducers. 
In the present research, the $E_{\max }(\mathrm{U} / \mathrm{L})$ of $F$. culmorum raised by increasing cutin concentration, being in accord with that previously reported (Hawthorne et al., 2001; Degani, 2015). However, the $Y_{E / X}(\mathrm{U} / \mathrm{g} / \mathrm{X})$ was higher in those media supplemented with low apple cutin concentrations $(0.2$ and $2 \mathrm{~g} / \mathrm{L})$ than in that medium added with $20 \mathrm{~g}$ of cutin/L (the highest cutin concentration tested). Macedo \& Pio (2005) reported that $F$. oxysporum showed the best conditions for the production of extracellular cutinase in a medium added with $10 \mathrm{~g}$ of cutin/L. Canavati-Alatorre et al. (2016) studied cutinase production by $F$. culmorum in media supplemented with glucose and apple cutin and found a $E_{\max }$ of $406 \mathrm{U} / \mathrm{L}$, which is similar to that observed in our results (using $20 \mathrm{~g}$ of cutin/L). Several techniques have been developed in order to identify cutinases in SDS-PAGE gels (Karpushova et al., 2005; CastroOchoa et al., 2012; Yang et al., 2013). The use of these techniques have revealed fungal cutinases of about $22 \mathrm{kDa}$ and $29 \mathrm{KDa}$ (Castro-Ochoa et al., 2012; Degani, 2015) and cutinolytic esterase produced by bacteria ranged in size from 29 to 47 kDa (Inglis et al., 2011). Soliday \& Kolattukudy (1976) reported that Fusarium roseum culmorum produced cutinases and non-specific esterases that hydrolyzed cutin, with a molecular weight of approximately $24.3 \mathrm{kDa}$. Canavati-Alatorre et al. (2016) studied cutinase production by F. culmorum grown on media supplemented with both glucose and apple cutin and observed cutinase activity bands with a molecular weight of approximately $50 \mathrm{kDa}$. In the present research, a cutinase activity band of around $65 \mathrm{KDa}$ was observed in zymograms of $F$. culmorum grown in the different apple cutin concentrations and an additional cutinase activity band of around $90 \mathrm{KDa}$ was also observed in zymograms of $F$. culmorum grown in the highest cutin concentration tested $(20 \mathrm{~g} / \mathrm{L})$. These studies showed that $F$. culmorum used apple cutin as the sole carbon source, which acted as a cutinase inducer. The highest-yielding parameters of cutinase were observed in $2 \mathrm{~g}$ of apple cutin/L. This research showed promising results in the cutinase induction for $F$. culmorum using a low concentration of apple cutin.

\section{ACKNOWLEDGEMENTS}

We are thankful to the Mexican Council for Science and Technology (CONACyT) for financial support (project No. 1549; Fronteras de la Ciencia). We also are grateful to CONACyT for providing a doctoral scholarship (No. 555469) to Angel González Márquez.

\section{CONFLICT OF INTEREST}

The authors declare that they have no conflict of interest. 


\section{REFERENCES}

Aguilar-Alvarado Y., Báez-Sánchez M.R., Martínez-Carrera D., Ahuactzin-Pérez M.,Cuamatzi-Muñoz M. \& Sánchez, C. 2015. Mycelial growth and enzymatic activities of fungi isolated from recycled paper wastes grown on di(2-ethylhexyl) phthalate. Polish Journal of Environmental Studies. 24(5): 1897-1902.

Ahuactzin-Pérez M., Tlecuitl-Beristain S., García-Dávila J., González-Pérez M., Gutiérrez-Ruíz M. C. \& Sánchez C. 2016. Degradation of di (2-ethyl hexyl) phthalate by Fusarium culmorum: Kinetics, enzymatic activities and biodegradation pathway based on quantum chemical modeling. Science of the Total Environment. 566-567: 1186-1193.

Bradford M. M. 1976. A rapid and sensitive method for the quantitation of microgram quantities of protein utilizing the principle of protein-dye binding. Analytical Biochemistry. 72: 248-254.

Canavati-Alatorre M. S., Águila I., Barraza-Soltero I. K., Castillón E., Correa-Barrón A. L., Sánchez-López E., Conde-Ávila V., González-Márquez A., Méndez-Iturbide D., Ruvalcaba D. \& Sánchez C. 2016. Growth and cutinase activity of Fusarium culmorum grown in solid-state fermentation. Mexican Journal of Biotechnology. 1 (2): 8-19.

Castro-Ochoa D., C. Peña-Montes A.. González-Canto A., Alva-Gasca R., EsquivelBautista A., Navarro-Ocaña A. \& Farrés A. 2012. ANCUT2, an extracellular cutinase from Aspergillus nidulans induced by olive oil. Applied Biochemistry and Biotechnology. 166: 1275-1290.

Chaudhari S. A. \& Singhal R. S. 2015. Cutin from watermelon peels: A novel inducer for cutinase production and its physicochemical characterization. International Journal of Biological Macromolecules.79: 398-404.

Chen S., Chen J. \& Wu J. 2013. Cutinase: Characteristics, preparation and application. Biotechnology Advances. 31(8): 1754-1767.

De Oliveira, C. T., Alves, E. A., Todero, I., Kuhn, R. C., de Oliveira, D., \& Mazutti, M. A. (2019). Production of cutinase by solid-state fermentation and its use as adjuvant in bioherbicide formulation. Bioprocess and Biosystems Engineering. 42 (5): 829838.

Degani O. 2015. Production and purification of cutinase from Fusarium oxysporum using modified growth media and a specific cutinase substrate. Advances in Bioscience and Biotechnology. 6: 245-258.

Ferrario V., Pellis A., Cespugli M., Guebitz G. M. \& Gardossi L. 2016. Nature inspired solutions for polymers: Will cutinase enzymes make polyesters and polyamides greener?. Catalysts. 6(12): 205. 
Ferrer-Parra L., López-Nicolas D. I., Martínez-Castillo R., Montiel-Cina J. P., Morales-Hernández A. R., Ocaña-Romo E., González-Márquez A., Portillo-Ojeda M., Sánchez-Sánchez D. F. \& Sánchez C. 2018. Partial characterization of esterases from Fusarium culmorum grown in media supplemented with di (2-ethyl hexyl phthalate) in solid-state and submerged fermentation. Mexican Journal of Biotechnology. 3(1):82-94.

Fett, W. F., Wijey, C., Moreau, R. A., \& Osman, S. F. 1999. Production of cutinase by Thermomonospora fusca ATCC 27730. Journal of Applied Microbiology. 86(4): 561-568.

Fich, E. A., Segerson, N. A., \& Rose, J. K. C. (2016). The Plant Polyester Cutin: Biosynthesis, Structure, and Biological Roles. Annual Review of Plant Biology, 67(1), 207-233.

Fraga P., Carvalho P. \& Macedo A.G. 2012. Production of cutinase by Fusarium oxysporum on Brazilian sgricultural by-products and its enantioselective properties. Food and Bioprocess Technology. 5: 138-146.

González-Márquez A., Loera-Corral O., Santacruz-Juárez E., Tlécuitl-Beristain S., García-Dávila J., Viniegra-González G. \& Sánchez, C. (2019). Biodegradation patterns of the endocrine disrupting pollutant di (2-ethyl hexyl) phthalate by Fusarium culmorum. Ecotoxicology and Environmental Safety 170: 293-299.

Hawthorne B. T., Rees-George J. \& Crowhurst R. N. 2001. Induction of cutinolytic esterase activity during saprophytic growth of cucurbit pathogens, Fusarium solani f. sp. cucurbitae races one and two (Nectria haematococca MPI and MPV, respectively). Federation of European Microbiological Societies Microbiology Letters. 194: 135-141.

Inglis G. D., Yanke L. J. \& Selinger L. B. 2011. Cutinolytic esterase activity of bacteria isolated from mixed-plant compost and characterization of a cutinase gene from Pseudomonas pseudoalcaligenes. Canadian Journal of Microbiology 57: 902-913.

Karpushova A., Brummer F., Barth S., Lange S. \& Schmid R. D. 2005. Clonning, recombinant expression and biochemical characterisation of novel esterases from Bacillus sp. associated with the marine sponge Aplysina aerophoba. Applied Microbiology and Biotechnology. 67: 59-69.

Kim Y. H., Ahn J. Y., Moon S. H. \& Lee J. 2005. Biodegradation and detoxification of organophosphate insecticide, Malathion by Fusarium oxysporum f. sp. pisi cutinase. Chemosphere. 60: 1349-1355.

Kim Y. H., Lee J. \& Moon S. H. 2003. Degradation of an endocrine disrupting chemical, DEHP [di-(2-ethylhexyl)-phthalate], by Fusarium oxysporum f. sp. pisi cutinase. Applied Microbiology and Biotechnology. 63: 75-80.

Kim Y. H., Seo H. S., Min J., Kim Y. C., Ban Y. H., Han K. Y., Park J. S., Bae K. D., Gu M. B., Lee J. 2007. Enhanced degradation and reduction of toxicity of di 2- 
ethylhexyl phthalate by Fusarium oxysporum f. sp. pisi cutinase. Journal of Applied Microbiology. 102: 221-228.

Laemmli U. K. 1970. Clea vage of structural proteins during the assembly of the head of bacteriophage T4. Nature. 15,227(5259): 680-685.

Lin T. \& Kolattukudy P. 1978. Induction of a biopolyester hydrolase (Cutinase) by low levels of cutin monomers in Fusarium solani f. sp. Pisi. Journal of Bacteriology. 133: $942-951$.

Macedo G. A. \& Pio T. F. 2005. A rapid screening method for cutinase producing microorganisms. Brazilian Journal of Microbiology. 36(4): 388-394.

Nyyssölä, A. 2015. Which properties of cutinases are important for applications?. Applied Microbiology and Biotechnology. 99(12): 4931-4942.

Pio, T. F., \& Macedo, G. A. (2009). Chapter 4 Cutinases: Properties and Industrial Applications. Advances in Applied Microbiology. 77-95.

Purdy R. E. \& Kolattukudy P. E. 1973. Depolymerization of hydroxy fatty acid biopolymer, cutin, by an extracelular enzyme from Fusarium solani f. pisi isolation and some properties of the enzyme. Archives of Biochemistry and Biophysics. 159: 61-69.

Soliday C. L. \& Kolattukudy P. E. 1976. Isolation and characterization of a cutinase from Fusarium roseum culmorum and its immunological comparison with cutinases from F. solani pisi. Archives of Biochemistry and Biophysics. 176: 334-343.

Yang S., Xu H., Yan Q., Liu Y., Zhou P. \& Jiang Z. 2013. A low molecular mass cutinase of Thielavia terrestris efficiently hydrolyze poly(esters). Journal of Industrial Microbiology and Biotechnology. 40: 217-226. 